\section{Changes in vegetation diversity and composition following livestock removal along an upland elevational gradient}

\author{
G Matt Davies ${ }^{(1)}$, Julien Bodart ${ }^{(2)}$
}

European heathland habitats are cultural landscapes derived from previouslyforested ecosystems. Heathlands are of significant conservation interest but have experienced prolonged degradation due to a range of factors including overgrazing by domestic livestock. There is growing recognition of the need to restore upland landscapes to produce a diverse mosaic of woodlands, heathlands and forest edge ecotones. In some studies stock removal has been sufficient to promote heathland recovery, but often more intensive interventions are required. Few studies have specifically examined how abiotic gradients associated with changing elevation might relate to restoration success. We examined differences in vegetation between grazed and restored areas over a $\mathbf{5 0 0}$ $m$ elevational gradient split across two hillsides that were part of a landscapescale restoration project in the Scottish Southern Uplands. Species alpha and gamma diversity showed non-linear responses to elevation but the effects of grazing differed between sites. Grazing increased diversity on the lower elevation site but reduced it at higher elevations. The differing effects of grazing with elevation can be interpreted in the context of levels of competition and likely impacts on rates of colonization and extinction. Differences in community composition were assessed using PERMANOVA, NMDS and Cluster Analysis and were primarily controlled by elevation with no significant effect of grazing. The keystone heathland species Calluna vulgaris was not recorded in any of our monitoring plots but some other dwarf shrubs were common. Changes in community structure following stock removal are slow on upland sites but initial impacts interact strongly with abiotic site conditions and pre-restoration vegetation composition. During large-scale restoration it is therefore vital to consider how widely-applied treatments might differ in their effects across landscapes. Changes in diversity may provide a useful early indicator of important ecological processes and likely directions of change.

Keywords: Calluna vulgaris, Community Change, Grazing, Heathland, Moorland, Restoration, Scotland

\section{Introduction \\ Calluna vulgaris-dominated heathlands are cultural landscapes, derived from previously- forested ecosystems, which have been sub- ject to human manipulation and management for several millennia. Heathlands are of in- ternational conservation importance (Thom- pson et al. 1995, García et al. 2013) and this}

is recognized in national and international legislation (Maddock 2011, EU Habitats Directive 92/43/EEC). They owe their open character to low-intensity traditional livestock grazing and managed burning (Webb 1998, Fernandes et al. 2013). Habitat degradation, associated with poorly-managed livestock grazing is, however, a global issue fa-

(1) School of Environment and Natural Resources, The Ohio State University, Kottman Hall, 2021 Coffey Road, 43210 Columbus, OH (USA); (2) Solway Centre for Environment and Culture, University of Glasgow, Rutherford/McCowan Building, Crichton University Campus, Dumfries DG1 4ZL (Scotland)

\section{@ G Matt Davies (davies.411@osu.edu)}

Received: Jan 12, 2015 - Accepted: Mar 18, 2015

Citation: Davies GM, Bodart J, 2015. Changes in vegetation diversity and composition following livestock removal along an upland elevational gradient. iForest 8: 582-589 [online 2015-04-22] URL: http://www.sisef.it/iforest/contents/?id=ifor1557-008

Communicated by: Arthur Gessler cing many tropical, semi-arid and temperate ecosystems (Moleele \& Perkins 1998, D’Odorico et al. 2012, Fagúndez 2012). Significant potential exists for livestock grazing to induce dramatic changes in ecosystem state from which restoration can be difficult ( $\mathrm{Su}-$ ding et al. 2004). Throughout Europe large areas of heathland habitat have become increasingly degraded over the last century (Fagúndez 2012). Calluna-dominated communities have been lost due to changes to managed fire regimes (Ascoli et al. 2013); nutrient deposition associated with atmospheric pollution (Friedrich et al. 2011, Bobbink \& Hettelingh 2011); acid deposition (Bakker \& Berendse 1999); and land-use conversion (Hester et al. 1996). In the United Kingdom there are a growing number of agencies and organisations focused on landscape-scale ecosystem restoration in the uplands. Objectives are often focused on tree planting and the restoration of forest ecosystems (see Hobbs 2009 for an overview), but there is also recognition of the desirability of restoring forest ground flora and a diverse mosaic of habitat types that includes woodlands, heathlands and forest edge ecotone communities (Humphrey et al. 2003). Degraded heathlands are often dominated by competitive grass species such as Molinia caerulea (purple moor grass) and Nardus stricta (moor matgrass). Both of these can attain high levels of abundance, lead to communities with relatively low levels of diversity and can pose significant challenges for restoration practice (Grant et al. 1996, Marrs et al. 2004). A number of studies have examined the effects of grazing regimes on heathland communities, often concluding that restoration prescriptions need to be sitespecific. For example, whilst it has proved possible to facilitate heathland recovery by simply reducing grazing pressure (Anderson \& Radford 1994, Hulme et al. 1999, Hulme et al. 2002), often it has taken additional interventions to allow Calluna establishment. Successful treatments have included soil disturbance by cattle trampling, rotavation, herbicide application and reseeding (Marrs et al. 2004, Mitchell et al. 2008) and, where nutrient enrichment is an issue, topsoil removal (Verhagen et al. 2001). Such intensive restoration actions may require managers to make difficult trade-offs as they may maximize Calluna cover but can also lead to the loss of other components of the community (Littlewood et al. 2006).

Many of the differences seen between studies can be ascribed to variation in the initial floristic composition of the sites undergoing restoration, and the abundance of Calluna within the community or seed-bank. A few studies have taken a multi-site perspective and assessed interactions between restoration and site edaphic characteristics and initial 
community composition (Rawes 1981, Welch \& Scott 1995, Bullock \& Pakeman 1997 Marrs et al. 2004). These have allowed authors to examine the extent to which general patterns can be discerned in post-restoration vegetation development, but untangling the effects of site-to-site differences in management history, vegetation, climate and soil type can still be difficult. Körner (2007) points to the power of elevational gradients in testing the response of systems to geophysical influences. It is long-established that edaphic characteristics play a strong role in defining the landscape-scale distribution of upland vegetation communities (Watt \& Jones 1948). However, variation in edaphic characteristics, including differences in soil type, soil fertility, climate and productivity, across abiotic ecotones can also interact with management to drive changes in vegetation communities (Common et al. 1998, Pakeman 2004, Vandvik et al. 2005).

This research took advantage of a realworld, landscape-scale restoration treatment to determine how initial vegetation responses to grazing removal interacted with the wide variation in elevation across the site Approximately half of our study-site was fenced-off in a single, landscape-scale exclosure during autumn 2010 (three years prior to this study). The site managers' aim was to allow establishment of planted native woodland and the recovery of semi-natural vegetation at the woodland edge and in sub-montane and montane zones. Since elevational gradients are known to be associated with patterns in both species diversity and overall community composition, we were interested in assessing whether there was variation in restoration potential with elevation and if elevation influenced the resistance of communities to change. Our specific objectives therefore included: (1) assessing how grazing removal and elevation interact to drive changes in species diversity; and (2) quantifying the extent to which grazing and elevation determine community composition.

\section{Material and methods}

\section{Study site}

Research was completed at Corehead, a 640 ha hill farm near Moffat in the Southern Uplands of Scotland (lat: $55^{\circ} 23^{\prime} 42^{\prime \prime} \mathrm{N}$, long: $\left.3^{\circ} 27^{\prime} 54^{\prime \prime} \mathrm{W}\right)$. Elevation at Corehead ranges from 200 to $800 \mathrm{~m}$ a.s.l. Local rainfall averages $1635 \mathrm{~mm} \mathrm{year}^{-1}$ with average annual maximum and minimum temperatures of 11.0 and $3.6{ }^{\circ} \mathrm{C}$, respectively (Adair 2009). Corehead has been the property of the Borders Forest Trust since 2009, and they aim to maintain low intensity upland sheep farming on a proportion of the site whilst restoring a mosaic of native habitats, including deciduous woodland, heathland and montane scrub.
Research was split between two study sites - Linshaw Knowe (max. elevation $500 \mathrm{~m}$ ) and Hartfell (max. elevation $808 \mathrm{~m}$ ). Soil types (as per Soil Survey of Scotland Staff 1981; WRB soil types provided in brackets) ranged from brown earths (cambisols) at the lowest elevations, through peaty podzols (umbrisols/podzols) at higher elevations to montane soils (umbrisols) on the summit of Hartfell. Underlying geology consists of greywackes (sandstone) with shale bands. Prior to restoration, vegetation at Corehead was typical of the relatively heavily grazed hills of northern and western Great Britain. At Linshaw Knowe it was dominated by a species-poor mixture of Festuca ovina Agrostis capillaris - Galium saxatile grassland (National Vegetation Classification, NVC - Rodwell 1992, community U4); Nardus stricta - Galium saxatile grassland (NVC U5) and Pteridium aquilinum - Galium saxatile - Anthoxanthum odoratum grassland (NVC U20b) (Adair 2009). On Hartfell vegetation graded from Nardus stricta - Galium saxatile grassland (NVC U5) into Carex bigelowii - Racomitrium lanuginosum moss-heath (NVC U10) at the highest elevations (Adair 2009). Calluna was absent from large areas of the study site but patches remained in areas naturally-protected from grazing (steep slopes, gullies, etc.). The presence of such patches, combined with local oral history, suggests these habitats were formerly more extensive.

Stock were removed from half of Corehead in 2010 using a landscape-scale exclosure. Prior to removal stock numbers varied across the site. There were approximately 2.8 ewes $\mathrm{ha}^{-1}$ on Linshaw Knowe and 1.6 ewes ha ${ }^{-1}$ on Hartfell. A small number of cattle were also grazed during the summer. Historic grazing pressure is likely to have been substantially higher. Nutrient export from livestock production can compensate for atmospheric inputs (Fottner et al. 2007) and thus, on managed heathlands like our study-site, loss of Calluna dominance is mostly associated with over-grazing by livestock (Stevenson \& Thompson 1993, Alonso et al. 2009).

\section{Design and monitoring}

Pseudoreplication (sensu Hurlbert 1984) is a troublesome though unavoidable issue in "natural experiments" such as ours. Pseudoreplication can arise when researchers define a hypothesis and collect what they deem to be independent samples from two populations they wish to compare. In reality the samples are not independent because, for example, each sample is collected from a single monitoring unit and treatment effects can be confounded with background variation in biotic and abiotic conditions. We agree with Hargrove \& Pickering (1992), Oksanen (2001) and Kozlov \& Hurlbert (2006) that this means hypotheses need to be framed carefully, acknowledging what statistical inferences can and cannot be made. As our site consists of a single exclosure we acknowledge at the outset that samples taken in grazed and ungrazed areas can only be considered independent samples of each side of the fence at our specific site. We therefore test the hypothesis that there are differences in vegetation diversity and composition on either side of the fence at our site. We cannot conclude on the basis of our statistical analysis that any differences observed are the result of grazing removal. As Hargrove \& Pickering (1992) point out, we can form "how possibly" hypotheses to suggest explanations for the patterns we observe.

Study sites were selected to allow direct comparisons of communities still used for sheep grazing and those that had been protected by fencing for nearly three years. We aimed to capture variation in the effects of grazing across an ecotone that included a transition from the moorland-fringe into montane communities. Due to the position of fencing and land-ownership this involved splitting the ecotone across the two sites previously described. Monitoring plots were established at $50 \mathrm{~m}$ intervals in elevation including three elevations on Linshaw Knowe (400-500 m) and five on Hartfell (600-800 $\mathrm{m})$. Locations were chosen to have similar aspects (S-SSW), though the convex profile of the hillslopes meant slopes declined with elevation at both sites. At each elevation we placed ten $1 \times 1 \mathrm{~m}$ monitoring plots (five on each side of the fence) along the contour at $10 \mathrm{~m}$ intervals from the boundary. The two groups of plots, grazed and ungrazed, at each elevation were deliberately located close to each other and to the fence, to ensure that management history and underlying hydrological and soil conditions were similar.

Within each plot we made visual estimates of the cover (nearest $1 \%$ ) of all vascular plant species and litter cover. Cryptogams were recorded by functional group (acrocarpous mosses, lichens pleurocarpous mosses, Sphagnum spp.). A number of species could not be readily distinguished in the field. In particular it proved difficult to reliably separate Carex bigelowii (Bigelow's sedge) from montane forms of Carex nigra (common sedge), whilst Agrostis canina (velvet bent) and Agrostis vinealis (brown bent) could not be distinguished without causing undue disturbance to the plots. These species were therefore pooled for analysis. Species nomenclature follows Stace (2010). The raw data used in the analysis are provided in Appendix 1 .

\section{Data analysis}

\section{Species richness and diversity}

Species richness and species diversity (Shannon-Weiner Index) were calculated for 
all eighty plots using the "specnumber" and "diversity" functions in the "vegan" package (Oksanen et al. 2014) of the software R version 2.15.0 ( $\mathrm{R}$ Development Core Team 2012). Differences in richness and diversity were analyzed using a linear model in R. We tested for the effects of site, SoF (side of the fence - grazed or ungrazed) and elevation. Since site and elevation were confounded, we specified elevation as nested within sites. We analyzed changes in litter cover (square root transformed) in the same way.

Differences in beta diversity across elevations and between sides of the fence were characterized using the "betadisper" function in the "vegan" package of $\mathrm{R}$ with the BrayCurtis Dissimilarity Index based on all species and raw abundances (Anderson et al 2006). Beta diversity was defined as the average distance to the group centroid for each combination of grazing status and elevation. We used a linear model to test for differences in beta diversity according to SoF and elevation within sites. We also estimated gamma diversity for each elevation/ grazing combination by calculating the total number of species recorded across the relevant subset of plots.

\section{Community composition}

We used hierarchical agglomerative cluster analysis to identify recognizable community types across our site. Analysis was completed with the "hclust" function in $\mathrm{R}$ using the Bray Curtis dissimilarity index and Ward's method. The appropriate number of groups was identified by examining scree plots while considering the need for ease of interpretation.

We tested for the effects of site, SoF and elevation on species composition using Permutational Multivariate Analysis of Variance (PERMANOVA - Anderson 2001). Tests were completed in $\mathrm{R}$ using the "adonis" function in the "vegan" package. Here we were interested in broad differences in community composition so we removed rare species (those occurring in $<5 \%$ of plots) as these can exert a strong influence on differences between plots. Prior to analysis we also applied a "wisconsin" double standardization (by species maximum and total plot cover). Analysis was completed using the Bray-Curtis Dissimilarity Index and 10000 permutations. As site was confounded with elevation we first tested for the effects of site and SoF (including interactions) before examining the effects of elevation and SoF. For the latter test we restricted permutations to within sites.

Non-Metric Multidimensional Scaling (NMDS) was used to visualize variation in plot composition according to differences in site, elevation and grazing status. Analysis was completed using the "metaMDS" function in the "vegan" package of R. Data was

Tab. 1 - Results of linear models examining within-site effects of side of the fence (SoF grazing status), elevation and their interaction on species richness (top) and species diversity (Shannon-Weiner Index; bottom). For all tests the d.f. for each term were 1.26 for Linshaw Knowe and 1.46 for Hartfell.

\begin{tabular}{llrrrrrc}
\hline \multirow{2}{*}{ Group } & \multirow{2}{*}{ Parameter } & \multicolumn{3}{c}{ Linshaw Knowe } & \multicolumn{3}{c}{ Hartfell } \\
\cline { 3 - 8 } & & Coeff. & F & $\boldsymbol{p}$ & Coeff. & \multicolumn{1}{c}{ F } & \multicolumn{1}{c}{$\boldsymbol{p}$} \\
\hline Richness & SoF & -17.167 & 7.71 & 0.010 & 9.560 & 0.68 & 0.415 \\
& Elevation & -0.016 & 0.02 & 0.904 & -0.002 & 8.89 & 0.004 \\
& SoF $\times$ Elevation & 0.034 & 4.26 & 0.049 & -0.013 & 5.75 & 0.021 \\
\hline Diversity & SoF & -2.850 & 1.60 & 0.217 & 1.912 & 0.82 & 0.370 \\
& Elevation & -0.005 & 1.68 & 0.206 & -0.001 & 10.07 & 0.003 \\
& SoF $\times$ Elevation & 0.006 & 3.84 & 0.061 & -0.002 & 5.28 & 0.026 \\
\hline
\end{tabular}

pre-treated in the same way as for the PERMANOVA analysis. We examined one to six dimensional solutions and used a scree plot of stress versus number of dimensions to select a solution that provided an adequate balance between simplicity and low stress. We investigated the relationship between plot composition and elevation using the "ordisurf" function. "ordisurf" uses a General Additive Model to fit a smooth surface for an environmental variable and plots the result on an ordination diagram (Bennion et al. 2012). We selected the optimal model complexity by varying the number of knots to minimize Generalized Cross Validation prediction error (GCV).

\section{Results}

\section{Species richness and diversity}

There were significant three-way interactions between site, SoF and elevation for both species richness $\left(\mathrm{F}_{[4,72]}=4.33 ; p=\right.$ $0.003)$ and species diversity $\left(\mathrm{F}_{[4,72]}=5.03 ; p\right.$ $=0.001)$. Differences in species richness and diversity on each side of the fence are conditional on site-specific, differing responses to changing elevation. Given the difficulty of interpreting such complex interactions we fitted two additional models to investigate the within-site effects of SoF and elevation (Tab. 1).

For species richness, there were significant interactions between grazing and elevation at both sites. On Linshaw Knowe richness increased with elevation in ungrazed plots but declined in grazed plots (Fig. 1). On Hartfell species richness decreased with elevation on both grazed and ungrazed sides but the effect was noticeably stronger for those that were ungrazed.

Species diversity was controlled by the interacting effects of SoF and elevation on Hartfell (Fig. 2). Diversity declined with elevation for both grazed and ungrazed plots but the effect was stronger for ungrazed plots. On Linshaw Knowe there was no significant effect of SoF or elevation on diversity. However, the interaction between these two effects was only marginally non-significant (Tab. 1). No significant effects of SoF or elevation were detected on beta diversity.

Differences in gamma diversity were a result of both grazing status and elevation (Fig. 3). Gamma diversity declined monotonically for grazed plots but appeared to follow a unimodal distribution on ungrazed plots. Gamma diversity was, in general, higher for grazed plots on the low elevation site but the opposite was true on the higher elevation site.

There was a significant three-way interaction of site, SoF and elevation on litter cover $\left(\mathrm{F}_{[4,72]}=4.19 ; p=0.004\right)$. Site-level models revealed significantly higher cover in ungrazed plots on Linshaw Knowe $\left(\mathrm{F}_{[1,26]}=38.63\right.$;

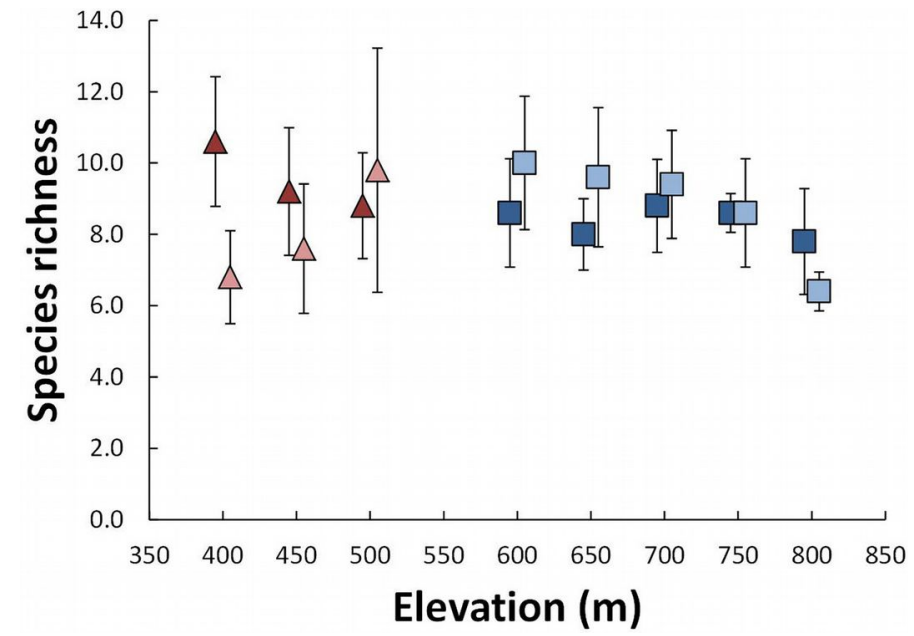

Fig. 1 - Average plot species richness as a function of site and elevation. Linshaw Knowe is shown as triangles and Hartfell as squares. Grazed and ungrazed plots are shown as dark and light colors, respectively. Error bars are \pm one standard deviation. 
Fig. 2 - Average plot species diversity (Shannon-Weiner Index) as a function of site and elevation. Linshaw

Knowe is shown as triangles and Hart-

fell as squares.

Grazed and ungrazed plots are

shown as dark and light colors, respectively. Error bars are

\pm one standard deviation.

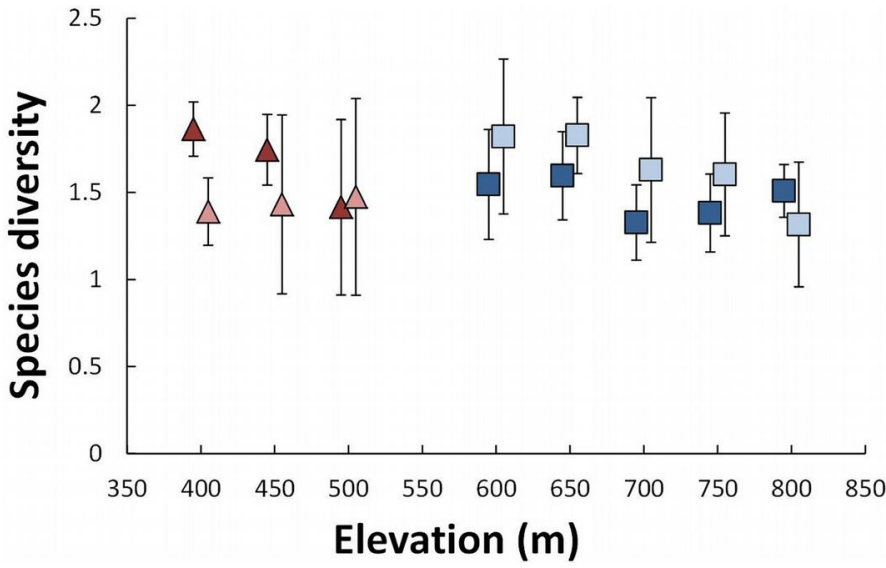

Fig. 3 - Total species richness (gamma diversity) across all plots in a given elevation/grazing combination. Linshaw Knowe is shown as triangles and Hartfell as squares. Grazed and ungrazed plots are shown as dark and light colors, respectively.

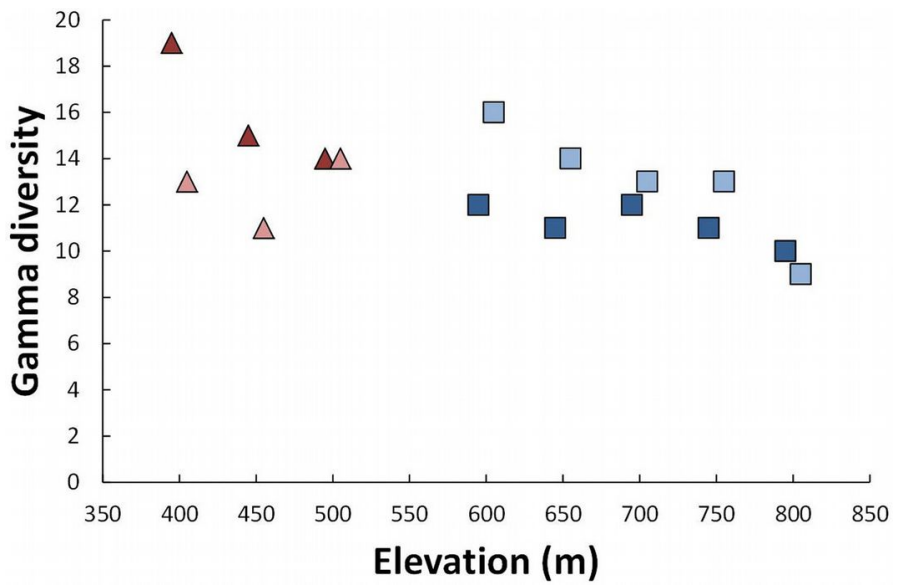

$p<0.001)$ and a significant decline in cover with elevation on Hartfell $\left(\mathrm{F}_{[1,46]}=11.65 ; p\right.$ $=0.001$ ).

\section{Community composition}

Cluster analysis identified six community groups that accounted for $76 \%$ of the variation in the dataset (Tab. 2, Fig. 4). No groups consisted solely of grazed or ungrazed plots. Community composition was best visualized by an NMDS with four dimensions $($ stress $=0.15$ ). The effect of elevation could be fitted to the resulting ordination using an ordisurface with 15 knots $(\mathrm{GCV}=$ $6822, \mathrm{R}_{\text {adj }}$ =0.71). The results showed that Linshaw Knowe and Hartfell host a number of distinct community types (Fig. 3), but there was a substantial degree of overlap at mid-elevations, where communities were dominated by Agrostis spp., N. stricta, Deschampsia flexuosa (wavy hair grass) and Vaccinium myrtillus (blaeberry - Fig. 4). The latter species was the only dwarf-shrub recorded and, on Hartfell, was dominant enough in places to form a separate community-type. M. caerulea was common across both sites, all elevations and both grazing treatments, but was particularly associated with the lower and upper elevations of Linshaw Knowe and mid-elevations on Hartfell. The highest elevations on Hartfell were clearly distinguished by the abundance of $C$. bigelowii/C. nigra and Juncus squarrosus (heath rush - Fig. 4). Whilst sites and elevations could be clearly distinguished in the ordination there was no obvious effect of SoF. This was confirmed by the results of the PERMANOVA: the first test revealed a significant effect of site (pseudo-F $=8.4, p<$ 0.001 ) but no effect of SoF or site/SoF interaction; the second test showed a significant effect of elevation within sites (pseudo-F = $11.8, p<0.001$ ) but no effect of SoF or grazing/elevation interaction.

\section{Discussion}

Changes in species richness and diversity

Previous research has recorded differing changes in heathland species diversity due to grazing control. Positive effects of grazing on diversity have been recorded by: (i) Bullock \& Pakeman (1997) who showed that grazing on lowland heath increased species richness by reducing shrub and scrub cover at the expense of grasses and forbs; (ii) Bokdam \& Gleichman (2000) showed increase in richness in Calluna and D. flexuosa dominated habitats in response to grazing by cattle; (iii) Britton et al. (2005) recorded increased richness in Racomitrium heath in response to heavy sheep grazing. In contrast, negative effects on species richness were recorded by Britton et al. (2005) in montane Vaccinium heaths. Other authors have found limited or mixed effects, for example Britton $\&$ Fisher (2007) found no effect of simulated grazing on the species richness of low-alpine Calluna heathland and Vandvik et al. (2005) found grazing led to reduced site-level species richness in dry heath but increased richness in moist heath.

Olff \& Ritchie (1998) reviewed the ways in

Tab. 2 - Community groups identified by cluster analysis. The table gives a community name and lists the dominant species (those with a mean relative cover $>0.1$. Frequency shows the number of plot community members with the numbers in brackets showing the number of grazed and ungrazed plots respectively. Symbol refers to the plotting symbol used for the community type in Fig. 4.

\begin{tabular}{llcc}
\hline Community group & Dominant species & Frequency & Symbol \\
\hline Blaeberry heath & Vaccinium myrtillus, Agrostis canina, Potentilla erecta & 7 & Circles \\
& & $(4 / 3)$ & 27 \\
\hline Mixed grassland & Potentilla erecta, Deschampsia flexuosa, Festuca ovina & $(14 / 13)$ & Squares \\
& & 6 & Diamonds \\
& Galium saxatile, Agrostis canina, Carex flacca, Molinia caerulea & $(4 / 2)$ & Gray triangles \\
\hline Bedstraw-bent grass grassland & & $(10 / 10)$ & 6 \\
\hline $\begin{array}{l}\text { Bigelow's sedge montane grass- } \\
\text { land }\end{array}$ & Carex bigelowii/nigra, Festuca ovina & White triangles \\
\hline Heath rush sub-montane grassland & $\begin{array}{l}\text { Juncus squarrosus, Carex bigelowii/nigra, Festuca ovina, } \\
\text { Molinia caerulea }\end{array}$ & 14 & $(5 / 9)$ \\
\hline Purple moor grass grassland & Molinia caerulea, Scirpus cespitosus, Potentilla erecta & Stars \\
\hline
\end{tabular}


Fig. 4 - NMDS ordination showing: (A) plots in relation to their site and grazing status (triangles: Linshaw

Knowe; squares: Hartfell; dark: grazed; light: ungrazed; hulls surround all plots on a site); (B) species centroids (see Appendix 2 for the list of species codes); (C) plots in relation to elevation, site and grazing status; (D) plots in relation to their community groups (see Tab. 1 for symbol codes).
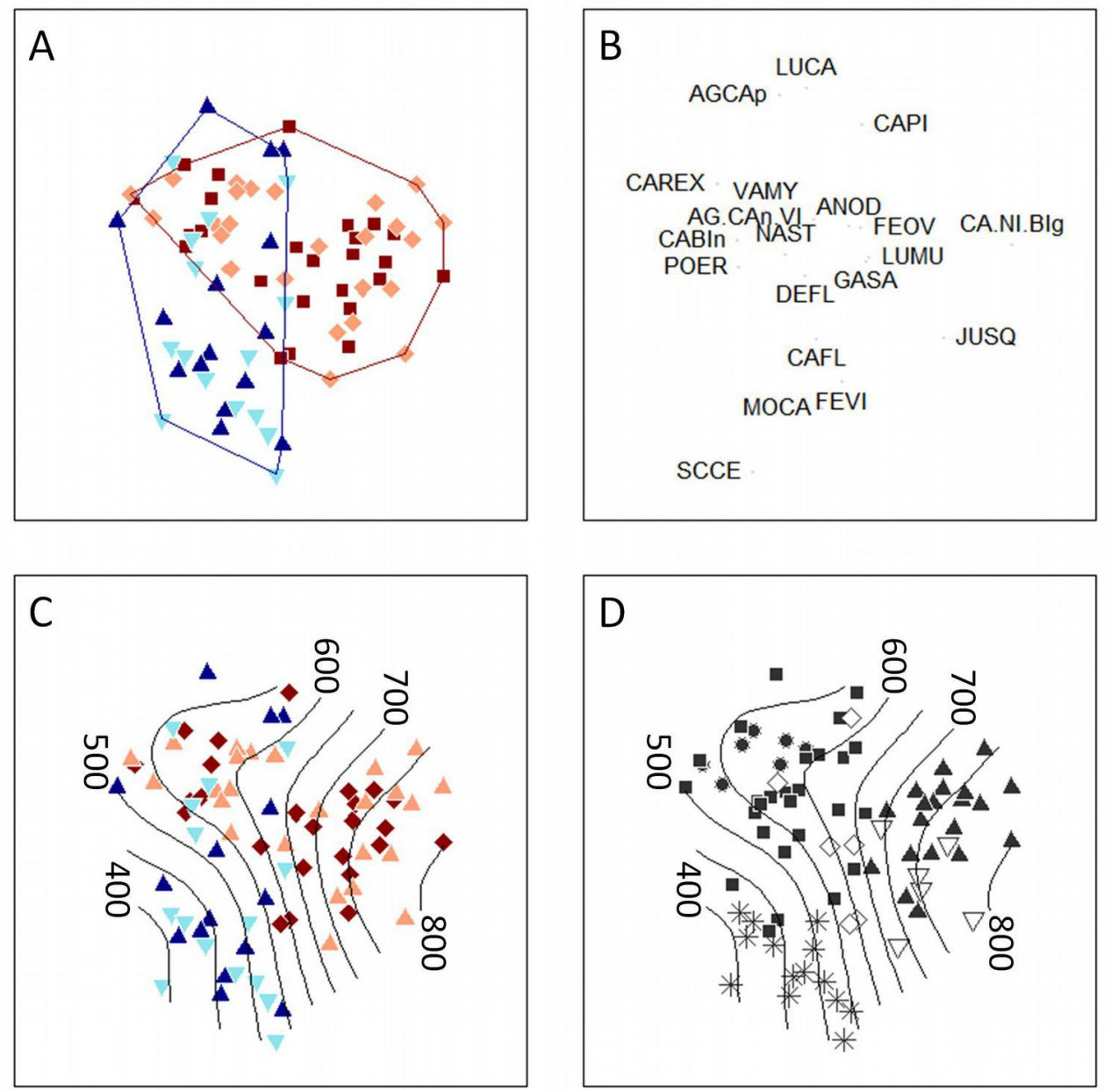

which grazing can affect the diversity of plant communities depending upon the intensity of grazing, grazer body size and site abiotic conditions. They also drew attention to the fact that the effects of grazing will vary across environmental gradients. Our analysis revealed complex relationships between species diversity and site, elevation and the side of the fence on which plots were located. As our study examined a single exclosure we cannot statistically state that differences between sides of the fence are due to grazing per se. However, with no major differences in aspect, soil moisture or soil type between grazed and ungrazed plots within each elevational band, there appears to be few other reasonable explanations for the patterns we observed. For both species richness and diversity there were significant three way interactions between the three variables included in our statistical models (site, elevation and side of fence). This complexity was a result of both differing elevational changes in diversity between grazed and ungrazed plots and an apparent unimodal distribution of richness and diversity across the entire gradient (Fig. 1 and Fig. 2). Gamma diversity displayed a similar pattern for ungrazed plots but there was a monotonic decline for grazed plots (Fig. 3). A number of explanations have been put forward to explain "humpbacked" patterns of diversity in response to elevation. These include the effect of range overlaps in transitions between zonal communities (Lomolino 2001), the "mass effect" (Grytnes et al. 2008) and the "mid-domain effect" (Colwell et al. 2009). Variations in management history (e.g., grazing intensity) are also likely to be important. The patterns we have recorded in alpha and gamma diversity suggest that changes to grazing regimes can modify processes controlling landscape-scale patterns of biodiversity. The removal of grazing seemed to alter the patterns of alpha and gamma diversity from monotonic declines with elevation to unimodal distributions with a peak around 600 m. Olff \& Ritchie (1998) suggest that grazing alters diversity by affecting the balance between extinction and colonization. At our more productive lower-elevation sites, grazing maintains diversity by creating microsites for species to establish through trampling (increased colonization) and redumass from competitive species and preventing the build-up of deep litter layers (reduced extinction). At the higher elevation Hartcing competition for light by removing bio- fell site there was no overall significant effect of grazing, but grazing did alter the change in diversity with elevation where the ungrazed $\mathrm{SoF}$ experienced a greater decline in diversity than the grazed SoF. Here the higher diversity on ungrazed plots from 600 $750 \mathrm{~m}$ elevation might be explained by grazing increasing extinction rates in locations already subject to more stressful abiotic conditions (e.g., low soil fertility, cool temperatures). The higher diversity in grazed plots at the highest elevation $(800 \mathrm{~m})$ is, however, more difficult to interpret, but it may be that disturbance associated with grazing breaks up the strong dominance of J. squarosus, $C$. bigelowii and $R$. lanuginosum and creates microsites for other species to establish.

Our research covers a relatively short period (ca. 3 years) since the restoration process began but nevertheless demonstrates that early monitoring can detect important variation in initial trajectories of vegetation development. The differences we recorded might also be explained by the fact that lowelevations will tend to be more productive and changes following restoration, such as plant growth and the build-up of layers of plant litter, may be faster in such zones. Further monitoring will be needed to determine 
long-term trajectories with confidence, but one important implication of our work is that the window for facilitating the establishment of absent keystone species, such as Calluna, may be rather limited in more productive locations if more intensive management is to be avoided.

\section{Changes in community composition}

Data on the effects of grazing on heathland communities can sometimes appear contradictory. Both Bullock \& Pakeman (1997) and Newton et al. (2009) revealed a tendency for grazing to reduce the relative abundance of Calluna compared to graminoids in lowland heaths. Nevertheless, managed grazing can form a successful strategy for the restoration of degraded heathland communities. For instance, Grant et al. (1996) and Common et al. (1998) showed that cattle grazing can be used to reduce the abundance of $N$. stricta; Critchley et al. (2008) found that combined cattle and sheep grazing can be used to reduce the abundance of $M$. caerulea; and Bullock \& Pakeman (1997) found heavy combined cattle and pony grazing reduced $M$. caerulea dominance on lowland heaths.

Community structure in our study was principally a function of elevation and site Although we recorded significant effects of grazing on species diversity, there was no evidence that its removal had significantly altered community structures or initiated a trajectory of development towards a Calluna-dominated habitat. All but one of the community types we identified were characterized by a mixture of grasses and sedges. $M$. caerulea was at least co-dominant in a number and this has substantial implications for future restoration success. Thus, similarly to previous studies, our research found that for grazing removal alone to initiate Calluna recovery it must be present in the prerestoration vegetation. $V$. myrtillus, which is able to regenerate vegetatively via rhizomes, was relatively abundant and appeared to have increased in ungrazed plots. The lack of Calluna regeneration in restored areas can therefore be ascribed to a depauperate seedbank, a lack of a local seed source and intense competition from competitive species. A Vaccinium-dominated community was identified on Hartfell but this shrub was also common on Linshaw Knowe and an alternative shrubland community type may thus develop in some ungrazed areas.

Previous studies on the restoration of upland heaths following over-grazing have had variable success with regards to the establishment of key dwarf shrub species. In many cases the removal or reduction of grazing by sheep has allowed Calluna to re-establish its dominance (Hulme et al. 2002, Pakeman et al. 2003, Fraser et al. 2011, Critchley et al. 2013) but this has certainly not been true everywhere (Rawes 1981, Littlewood et al. 2006), and success thus requires that Callu$n a$ be present in the pre-restoration vegetation. On M. caerulea or N. stricta dominated sites success in the restoration of Callunadominated communities has generally been associated with cattle grazing, ground disturbance by trampling or rotavation, herbicide application and reseeding (Marrs et al. 2004, Littlewood et al. 2006, Mitchell et al. 2008). However, long-term studies suggest that sites that have received minimal levels of disturbance during restoration (i.e., removal of grazing alone) tend to move closer to target conditions (Littlewood et al. 2014). Differences between studies can be ascribed both to variation in pre-restoration community composition, differences in the season, intensity and stock used in grazing experiments and site edaphic characteristics.

\section{Conclusions}

Studies of elevational changes in species diversity have played an important role in defining species' responses to geophysical variables and understanding patterns of species diversity at multiple scales (Körner 2007, Colwell et al. 2009). Our results make an important contribution to such work by demonstrating that spatial variation in management intensity can significantly modify such patterns. Grazing has disparate effects on ecosystem structure across elevational ecotones, and this must be considered when applying landscape-scale changes to management. At lower elevations disturbance plays a key role in moderating the dominance of competitive grasses and an alternative to grazing (e.g., herbicide, mechanical disturbance) will be required to prevent their dominance. At higher elevations grazing removal is to the benefit of species richness and diversity. Changes in upland vegetation following grazing removal are slow and we did not detect significant differences in community composition at our site three years after grazing was removed. Our data show changes in diversity can occur quickly and thus appear to be a valuable indicator of potential longer-term trajectories. Restoration of forest, woodland-edge and heathland ecosystems in sites degraded by over-grazing is a significant challenge in the British uplands, but simply removing or reducing grazing pressure may not always provide desirable outcomes. Managers proposing significant modification of upland landscapes should carefully track changes in species diversity in order to detect potentially undesirable trends.

\section{Acknowledgements}

This study was funded by the Borders Forest Trust (BFT), thanks to Phil Roe and Nicola Hunt for their support for the study. We also thank members of the BFT Core- head and Devil's Beeftub Steering Group, and Carol Woolliams in particular, for providing background knowledge. Paul Johnson (University of Glasgow) and Jon Bakker (University of Washington) provided statistical advice. We are grateful to two anonymous referees for their comments.

Author contributions: GMD conceived and designed the research and completed the statistical analyses; JB collected the field data and analysed species richness and diversity. GMD and JB wrote the manuscript.

\section{References}

Adair S (2009). Corehead National Vegetation Classification Survey with comments on management proposals. Full Report, Borders Forest Trust, Jedburgh, Scotland, pp. 38.

Alonso I, Hartley SE, Thurlow M (2009). Competition between heather and grasses on Scottish moorlands: Interacting effects of nutrient enrichment and grazing regime. Journal of Vegetation Science 12: 249-260. - doi: 10.2307/3236609

Anderson MJ (2001). A new method for non-parametric multivariate analysis of variance. Austral Ecology 26: 32-46. - doi: 10.1111/j.1442-9993. 2001.01070.pp.x

Anderson MJ, Ellingsen KE, McArdle BH (2006). Multivariate dispersion as a measure of beta diversity. Ecology Letters 9: 683-693. - doi: 10.11 11/j.1461-0248.2006.00926.x

Anderson P, Radford E (1994). Changes in vegetation following reduction in grazing pressure on the National Trust's Kinder Estate, Peak District, Derbyshire, England. Biological Conservation 69: 55-63. - doi: 10.1016/0006-3207(94)90328$\mathrm{X}$

Ascoli D, Lonati M, Marzano R, Bovio G, Cavallero A, Lombardi G (2013). Prescribed burning and browsing to control tree encroachment in southern European heathlands. Forest Ecology and Management 289: 69-77. - doi: 10.1016/j.foreco.2012.09.041

Bakker J, Berendse F (1999). Constraints in the restoration of ecological diversity in grassland and heathland communities. Trends in Ecology and Evolution 14: 63-68. - doi: 10.1016/S01695347(98)01544-4

Bennion H, Carvalho L, Sayer CD, Simpson GL, Wischnewski J (2012). Identifying from recent sediment records the effects of nutrients and climate on diatom dynamics in Loch Leven. Freshwater Biology 57: 2015-2029. - doi: 10.1111/j. 1365-2427.2011.02651.x

Bobbink R, Hettelingh JS (2011). Review and revision of empirical critical loads and dose-response relationships. In: Proceedings of an expert workshop. Noordwijkerhout (Netherlands), 23-25 Jun 2010. Coordination Centre for Effects, National Institute for Public Health and the Environment (RIVM), Bilthoven, The Netherlands, pp. 246.

Bokdam J, Gleichman JM (2000). Effects of grazing by free-ranging cattle on vegetation dynamics in a continental north-west European heathland. Journal of Applied Ecology 37: 415-431. - 
doi: 10.1046/j.1365-2664.2000.00507.x

Britton AJ, Fisher JM (2007). Interactive effects of nitrogen deposition, fire and grazing on diversity and composition of low-alpine prostrate $\mathrm{Cal}$ luna vulgaris heathland. Journal of Applied Ecology 44: 125-135. - doi: 10.1111/j.1365-2664.20 06.01251.x

Britton AJ, Pearce ISK, Jones B (2005). Impacts of grazing on montane heath vegetation in Wales and implications for the restoration of montane areas. Biological Conservation 125: 515-524. doi: 10.1016/j.biocon.2005.04.014

Bullock JM, Pakeman RJ (1997). Grazing of lowland heath in England: management methods and their effects on healthland vegetation. Biological Conservation 79: 1-13. - doi: 10.1016/S000 6-3207(96)00117-6

Colwell RK, Gotelli NJ, Rahbek C, Entsminger GL, Farrell C, Graves GR (2009). Peaks, plateaus, canyons, and craters: the complex geometry of simple mid-domain effect models. Evolutionary Ecology Research 11: 355-370. [online] URL: http://forskningsbasen.deff.dk/Share.external?sp=S87c8ecf0-3287-11df-8ed1-000ea68e96 $7 \mathrm{~b} \& \mathrm{sp}=\mathrm{Sku}$

Common TG, Wright IA, Grant SA (1998). The effect of grazing by cattle on animal performance and floristic composition in Nardus-dominated swards. Grass and Forage Science 53: 260-269. doi: 10.1046/j.1365-2494.1998.00138.x

Critchley CNR, Adamson HF, Mclean BML, Davies OD (2008). Vegetation dynamics and livestock performance in system-scale studies of sheep and cattle grazing on degraded upland wet heath. Agriculture, Ecosystems and Environment 128: 59-67. - doi: 10.1016/j.agee.2008.05.002 Critchley CNR, Mitchell RJ, Rose RJ, Griffiths JB, Jackson E, Scott H, Davies OD (2013). Reestablishment of Calluna vulgaris (L.) Hull in an eight-year grazing experiment on upland acid grassland. Journal for Nature Conservation 21: 22-30. - doi: 10.1016/j.jnc.2012.08.005

D’Odorico P, Okin GS, Bestelmeyer BT (2012). A synthetic review of feedbacks and drivers of shrub encroachment in arid grasslands. Ecohydrology 5: 520-530. - doi: 10.1002/eco.259

Fagúndez J (2012). Heathlands confronting global change: drivers of biodiversity loss from past to future scenarios. Annals of Botany 111 (2): 151172. - doi: $10.1093 / \mathrm{aob} / \operatorname{mcs} 257$

Fernandes PM, Davies GM, Ascoli D, Fernández C, Moreira F, Rigolot E, Stoof CR, Vega JA, Molina D (2013). Prescribed burning in southern Europe: developing fire management in a dynamic landscape. Frontiers in Ecology and the Environment 11: e4-e14. - doi: 10.1890/120298 Fottner S, Härdtle W, Niemeyer M, Niemeyer T, Von Oheimb G, Meyer H, Mockenhaupt M (2007). Impact of sheep grazing on nutrient budgets of dry heathlands. Applied Vegetation Science 10: 391-398. - doi: 10.1111/j.1654-109X. 2007.tb00438.x

Fraser MD, Theobald VJ, Dhanoa MS, Davies OD (2011). Impact on sward composition and stock performance of grazing Molinia-dominant grassland. Agriculture, Ecosystems and Environment
144: 102-106. - doi: 10.1016/j.agee.2011.08.004 Friedrich U, Von Oheimb G, Dziedek C, Kriebitzsch W, Selbmann K, Härdtle W (2011). Mechanisms of purple moor-grass (Molinia caerulea) encroachment in dry heathland ecosystems with chronic nitrogen inputs. Environmental Pollution 159: 3553-3559. - doi: 10.1016/j.envpol.2011. 08.010

García RR, Fraser MD, Celaya R, Mendes Ferreira LM, García U, Garcia KO (2013). Grazing land management and biodiversity in the Atlantic European heathlands: a review. Agroforestry Systems 87: 19-43. - doi: 10.1007/s10457-0129519-3

Grant SA, Torvell L, Sim EM, Small JL, Armstrong RH (1996). Controlled grazing studies on Nardus grassland: effects of between-tussock sward height and species of grazer on Nardus utilization and floristic composition in two fields in Scotland. Journal of Applied Ecology 33: 1053-1064. - doi: 10.2307/2404685

Grytnes JA, Heegaard E, Romdal TS (2008). Can the mass effect explain the mid-altitudinal peak in vascular plant species richness? Basic and Applied Ecology 9: 373-382. - doi: 10.1016/j.baae. 2007.05.001

Hargrove WW, Pickering J (1992). Pseudoreplication: a sine qua non for regional ecology. Landscape Ecology 6: 251-258. - doi: 10.1007/BF00 129703

Hester AJ, Miller DR, Towers W (1996). Landscape-scale vegetation change in the Cairngorms, Scotland, 1946-1988: implications for land management. Biological Conservation 77: 41-51. doi: 10.1016/0006-3207(96)80650-1

Hobbs R (2009). Woodland restoration in Scotland: ecology, history, culture, economics, politics and change. Journal of Environmental Management 90: 2857-2865. - doi: 10.1016/j.jenv man.2007.10.014

Hulme PD, Pakeman RJ, Torvell L, Fisher JM, Gordon IJ (1999). The effects of controlled sheep grazing on the dynamics of upland Agrostis-Festuca grassland. Journal of Applied Ecology 36: 886-900. - doi: 10.1046/j.1365-2664.1999.0045 2.x

Hulme PD, Merrell BG, Torvell L, Fisher JM, Small JL, Pakeman RJ (2002). Rehabilitation of degraded Calluna vulgaris (L.) Hull-dominated wet heath by controlled sheep grazing. Biological Conservation 107: 351-363. - doi: 10.1016/ S0006-3207(02)00073-3

Humphrey JW, Ferris F, Quine CP (2003). Biodiversity in Britain's planted forests. Forestry Commission, Edinburgh, UK, pp. 117. [online] URL: http://www.cabdirect.org/abstracts/200430 04865.html

Hurlbert SH (1984). Pseudoreplication and the design of ecological field experiments. Ecological Monographs 54 (2): 187-211. - doi: 10.2307/194 2661

Körner C (2007). The use of "altitude" in ecological research. Trends in Ecology and Evolution 22: 569-574. - doi: 10.1016/j.tree.2007.09.006

Kozlov MV, Hurlbert SH (2006). Pseudoreplication, chatter, and the international nature of sci- ence: a response to DV Tatarnikov. Journal of Fundamental Biology (Moscow) 67: 145-152. [online] URL: http://www.bio.sdsu.edu/pub/stuart/2006KozlovPrplnChatterEngl.pdf

Littlewood NA, Pakeman RJ, Woodin SJ (2006). A field assessment of the success of moorland restoration in the rehabilitation of whole plant assemblages. Applied Vegetation Science 9: 295-306. - doi: 10.1111/j.1654-109X.2006.tb00 679.x

Littlewood NA, Greenwood S, Quin SLO, Pakeman RJ, Woodin SJ (2014). Long-term trends in restored moorland vegetation assemblages. Community Ecology 15: 104-112. - doi: 10.1556/ ComEc.15.2014.1.11

Lomolino MV (2001). Elevation gradients of species density: historical and prospective views. Global Ecology and Biogeography 10: 3-13. doi: 10.1046/j.1466-822x.2001.00229.x

Marrs RH, Phillips JDP, Todd PA, Ghorbani J, Le Duc MG (2004). Control of Molinia caerulea on upland moors. Journal of Applied Ecology 41: 398-411. - doi: 10.1111/j.0021-8901.2004.0090 1. $\mathrm{x}$

Maddock A (2011). UK biodiversity action plan priority habitat descriptions. JNCC, Peterborough, UK, pp. 100. [online] URL: http://jncc. defra.gov.uk/PDF/UKBAP_PriorityHabitatDescRev2011.pdf

Mitchell RJ, Rose RJ, Palmer SCF (2008). Restoration of Calluna vulgaris on grass-dominated moorlands: the importance of disturbance, grazing and seeding. Biological Conservation 141: 2100-2111. - doi: 10.1016/j.biocon.2008.06 .006

Moleele NM, Perkins JS (1998). Encroaching woody plant species and boreholes: is cattle density the main driving factor in the Olifants Drift communal grazing lands, south-eastern Botswana? Journal of Arid Environments 40: 245-253. doi: 10.1006/jare.1998.0451

Newton AC, Stewart GB, Myers G, Diaz A, Lake S, Bullock JM, Pullin AS (2009). Impacts of grazing on lowland heathland in north-west Europe. Biological Conservation 142: 935-947. doi: 10.1016/j.biocon.2008.10.018

Oksanen J, Blanchet FG, Kindt R, Legendre P, Minchin PR, O'Hara RB, Simpson GL, Solymos P, Stevens MHH, Wagner H (2014). vegan: community Ecology Package. R package version 2.03 , web resource. [online] URL: http://CRAN.Rproject.org/package $=$ vegan

Oksanen L (2001). Logic of experiments in ecology: is pseudoreplication a pseudoissue? Oikos 94: 27-38. - doi: 10.1034/j.1600-0706.2001.113 11.x

Olff H, Ritchie ME (1998). Effects of herbivores on grassland plant diversity. Trends in Ecology and Evolution 13: 261-265. - doi: 10.1016/S01 69-5347(98)01364-0

Pakeman RJ (2004). Consistency of plant species, trait responses to grazing along a productivity gradient: a multi-site analysis. Journal of Ecology 92: 893-905. - doi: 10.1111/j.0022-0477.20 04.00928.x

Pakeman R, Hulme PD, Torvell L, Fisher JM 
(2003). Rehabilitation of degraded dry heather (Calluna vulgaris (L.) Hull) moorland by controlled sheep grazing. Biological Conservation 114: 389-400. - doi: 10.1016/S0006-3207(03)00 067-3

R Development Core Team (2012). R: a language and environment for statistical computing. $\mathrm{R}$ Foundation for Statistical Computing, Vienna, Austria. [online] URL: http://www.R-project.org Rawes M (1981). Further results of excluding sheep from high-level grasslands in the North Pennines. Journal of Ecology 69: 651-669. - doi: $10.2307 / 2259690$

Rodwell JS (1992). British plant communities: volume 3. Grasslands and montane communities. Cambridge University Press, Cambridge, UK, pp. 552.

Soil Survey of Scotland Staff (1981). Soil maps of Scotland at a scale of 1:250 000. Macaulay Institute for Soil Research, Aberdeen, Scotland, UK. [online] URL: http://mapapps2.bgs.ac.uk/ukso/ home.html?layer $=$ JH1SoilsOfScotland

Stace C (2010). New flora of the British isles. Cambridge University Press, Cambridge, UK, pp. 1236. [online] URL: http://books.google.com/books?id=nJ3YP28EjscC
Stevenson AC, Thompson DBA (1993). Longterm changes in the extent of heather moorland in upland Britain and Ireland: palaeoecological evidence for the importance of grazing. The Holocene 3: 70-76. - doi: 10.1177/09596836930 0300108

Suding KN, Gross KL, Houseman GR (2004). Alternative states and positive feedbacks in restoration ecology. Trends in Ecology and Evolution 19: 46-53. - doi: 10.1016/j.tree.2003.10.005

Thompson DBA, MacDonald AJ, Marsden JH, Galbraith CA (1995). Upland heather moorland in Great Britain: a review of international importance, vegetation change and some objectives for nature conservation. Biological Conservation 71: 163-178. - doi: 10.1016/0006-3207(94)00043-P Vandvik V, Heegaard E, Måren IE, Aarrestad PA (2005). Managing heterogeneity: the importance of grazing and environmental variation on postfire succession in heathlands. Journal of Applied Ecology 42: 139-149. - doi: 10.1111/j.1365-26 64.2005.00982.x

Verhagen R, Klooker J, Bakker JP, Van Diggelen R (2001). Restoration success of low-production plant communities on former agricultural soils after top-soil removal. Applied Vegetation Sci- ence 4: 75-82. - doi: 10.1111/j.1654-109X.200 1.tb00236.x

Watt AS, Jones EW (1948). The ecology of the Cairngorms: part 1. The environment and the altitudinal zonation of the vegetation. Journal of Ecology 36: 283-304. - doi: 10.2307/2256671

Webb NR (1998). The traditional management of European heathlands. Journal of Applied Ecology 35: 987-990. - doi: 10.1111/j.1365-2664.19 98.tb00020.x

Welch D, Scott D (1995). Studies in the grazing of heather moorland in northeast Scotland. VI. 20 -year trends in botanical composition. Journal of Applied Ecology 32: 596-611. - doi: 10.2307/ 2404656

\section{Supplementary Material}

Appendix 1 - Raw data used in analysis.

Link: Davies_1557@suppl001.xlsx

Appendix 2 - List of species codes used in Fig. 3.

Link: Davies_1557@supp1002.pdf 